\title{
OVERVIEW OF RESEARCH OF MUSHROOMS IN SRI LANKA
}

\author{
PANORÁMICA DE LA INVESTIGACIÓN DE HONGOS EN SRI LANKA
}

\author{
Samantha C. Karunarathna', 2*, Peter E. Mortimer ${ }^{1,2}$, Jianchu $\mathrm{Xu}^{1,2}$ and Kevin D. Hyde ${ }^{1,2,3}$
}

\begin{abstract}
${ }^{1}$ Key Laboratory of Economic Plants and Biotechnology, Kunming Institute of Botany, Chinese Academy of Sciences, 132 Lanhei Road, Kunming 650201, China. ${ }^{2}$ World Agroforestry Centre, East and Central Asia Office, 132 Lanhei Road, Kunming 650201, China. ${ }^{3}$ Center of Excellence in Fungal Research, Mae Fah Luang University, Chiang Rai 57100, Thailand.
\end{abstract}

*Corresponding author (samanthakarunarathna@gmail.com)

\section{SUMMARY}

According to recent estimates the mycota of Sri Lanka is highly diverse, yet it has been relatively little studied and remains poorly understood. Sri Lanka may contain up to 25,000 species of fungi, of which only a little more than 2000 are presently known, and this estimate does not take into account the large number of exotics introduced along with food, plantation, and ornamental plants. Mycological research in Sri Lanka has been limited to certain parts of the country, and the available information is widely dispersed, difficult to access, and plagued by synonymy. Commercially cultivable mushrooms were first introduced to Sri Lanka in 1985, and today both endemic and non-native species are cultivated. This paper addresses the current status of Sri Lankan mushroom research, and suggests measures which are needed to support the future development of Sri Lankan mycology.

Index words: Biodiversity, edible mushrooms, macrofungi, medicinal mushrooms.

\section{RESUMEN}

Según estimaciones recientes la micota de Sri Lanka es muy diversa, pero ha sido relativamente poco estudiada y sigue siendo mal entendida. Sri Lanka puede contener hasta 25,000 especies de hongos, de las cuales sólo se conocen actualmente algo más de 2000 , y esta estimación no tiene en cuenta el gran número de materiales exóticos introducidos junto con los alimentos, las plantaciones y las plantas ornamentales. La investigación micológica en Sri Lanka se ha limitado a ciertas partes del país, y la información disponible está muy dispersa, de difícil acceso y plagada de sinónimos. Los hongos comercialmente cultivables se introdujeron por primera vez en Sri Lanka en 1985 y actualmente se cultivan tanto especies endémicas como no nativas. Este artículo aborda el estado actual de la investigación de hongos de Sri Lanka, y sugiere medidas que son necesarias para apoyar el desarrollo futuro de la micología de Sri Lanka.

Palabras clave: Biodiversidad, hongos comestibles, macrohongos, hongos medicinales.

\section{INTRODUCTION}

Tropical and subtropical regions are potentially the richest source of new fungal species and Sri Lanka, though small in area, is no exception. This is due in part to the close juxtaposition of areas which differ widely in altitude and rainfall. Relatively few studies have been carried out on
Sri Lankan mycota, and the information available is widely scattered. Arriving at an accurate estimate of Sri Lankan fungi is further complicated by inconsistencies in synonyms used and duplicated entries across different studies. The works of D. N. Pegler and T. Petch together with a large collection of original illustrations of Agarics are deposited in the library at the Royal Botanical gardens, Peradeniya, but very few publications of a later date are seen. Pegler and Petch's macrofungi collections, moreover, are deposited at Kew. This lack of original collections and types complicates the identification of synonymies amongst macrofungi, as it is both costly and time-consuming to borrow herbarium specimens from Kew. Collections of soil and plant pathogenic fungi in Sri Lanka and the relevant literature are more complete and up to date because of their obvious economic importance.

The earliest Sri Lankan fungi to be recorded were Peziza ceylonische and P. lembosa described in Houttuyn (1783). The number of described species had risen to over 2,000 in about 640 genera, due to the efforts of Berkeley and Broome (1870, 1871, 1873), Petch (1908a, 1908b, 1910, 1913, 1915a, 1915b, 1916a, 1916b, 1916c, 1917a, 1917b, 1919, 1922, 1923, 1924a, 1924b, 1924c, 1924d, 1925, 1926a, 1926b, 1927, 1928, 1945, 1947), and Petch and Bisby (1950).

Various handbooks (Man and Biosphere, or MAB) on fungi parasitic on plants, associated with insects, or found in soil were published in the 1970s and 1980s, such as Coomaraswamy (1979a, 1979b), Coomaraswamy and De Fonseka (1981), and Coomaraswamy and Kumarasingham (1988). Also, the comprehensive book Agaric Flora of Sri Lanka was published by D. N. Pegler in 1986. The majority of references to Sri Lankan fungi, however, are still scattered across journals, University publications, research institutions, reports, proceedings and theses. A list of fungal plant pathogens and host names, prepared by $S$. Sivanathan (unpublished) is currently being updated. 
Certain fungal groups have been researched more thoroughly than others, because of their prominence (macrofungi), or practical importance (phytopathogens and mycorrhizae). In Sri Lanka only 130 Myxomycota (earlier in Kingdom fungi and now in Protozoa) species in 30 genera have been recorded (Petch and Bisby, 1950) and thereafter there are no records in the published literature. Seventytwo species of mostly soil-inhabiting Zygomycota have been recorded in 17 genera, and 252 mostly entomo- or phytopathogens species of Ascomycetes have also been recorded.

Records of species in the order Uredinales include Uredo (58 species), Puccinia (41 species), Aecidium (20 species), Uromyces (19 species), Ravenelia (8 species), Phragmidium (4 species), Melampsora (4 species), Coleosporium (3 species), Diorchidium (3 species), Pucciniastrum (2 species), Hemileia (1 species), Blastopota (1 species), Ceratolium (1 species), Cystospora (1 species) and Scopella (1 species), making a total of 167 species (Berkeley and Broome, 1870-1877; Petch; 1908-1947; Petch and Bisby, 1950). In the 'Aphyllophorales' (Polyporales in modern molecular phylogeny based classification), 342 species in 51 genera have been recorded. The dominant genera are Polyporus (57 species), Fomes/Rigidoporus (32 species), Poria (23 species), Stereum (26 species) and Trametes (no number given). In Gasteromycetes (now known as gasteroid fungi) 75 species in 37 genera have been recorded, the dominant genera being Geastrum (9 species) and Cyathus (4 species). In Ustilaginales, 25 species belonging to 7 genera have been recorded; in Exobasidiales 2 species belonging to a single genus have been recorded, and in Agaricales 513 species belonging to 50 genera have been recorded, making a grand total of 1125 species in 162 genera for Sri Lanka (Berkeley and Broome, 1870-1877; Petch, 19081947; Petch and Bisby; 1950).

The best known fungal group in Sri Lanka is the larger Basidiomycetes, with records of 513 species of Agarics in 50 genera such as Marasmius 53 spp., Psalliota (Agaricus) 35 spp., Hygrophorus 27 spp., Lentinus 14 spp. and Pleurotus 12 spp. (Petch and Bisby, 1950; Coomaraswamy, 1979a, 1979b; Coomaraswamy and De Fonseka, 1981; Coomaraswamy and Kumarasingham, 1988). The Herbarium of Horticultural Crop Research and Development Institute (HORDI), Gannoruwa, Peradeniya has a collection of 412 paintings of agarics by W. de Alwis (1842-1916), a Sri Lankan artist and entomologist, which are now available in digital form.

\section{RESEARCH ON MACROFUNGI}

Very few studies have been carried out on the taxonomy and phylogeny of macrofungi in Sri Lanka over the past two decades, while Houttuyn (1783), Berkeley and Broome (1870-1877), Petch (1905-1925), Petch and Bisby (1950), Coomaraswamy (1979a, 1979b), Pegler (1986) and Coomaraswamy and Kumarasingham (1988) have done lot of work on macrofungi based only on morphological characteristics. More than 500 Agaricoid genera collected by G. Gardner, who was the Superintendent of the Royal Botanic Gardens, Peradeniya during 1844-1849, have been described or recorded by M. J. Berkeley. Gardner was helped by G. H. K. Thwaites, and over 1200 dried specimens were sent to M. J. Berkeley at Kew, for identification.

Four hundred and three agaric species were reported by Berkeley and Broome, of which 305 were described as new species and provided with type collections (Berkeley and Broome; 1870, 1871, 1873). A few years after Berkeley and Broome's publications, Cesati (1879) described several agaric species based on O. Beccari's collections in 1865. F. V. Höehnel rediscovered some of Berkeley and Broome's specimens during his visit to Sri Lanka in 1907 (Höehnel, 1908, 1909, 1914). T. Petch, the appointed Mycologist at Peradeniya Royal Botanic Gardens, collected many mushrooms on the island and several of his accounts were published during 1905-1925.

Recent publications on agarics involve the genera Lepiota (Pegler, 1972) and Inocybe (synonym: Asterosporina) (Horak, 1979, 1980), and the family Entolomataceae (Pegler, 1977; Horak, 1980). Lentinus giganteus Berk. was recently moved to Pleurotus based on Thai and Sri Lankan collections (Karunarathna et al., 2011), and Agaricus hanthanaensis Karun. \& K.D. Hyde from Kandy district in the central Province of Sri Lanka was described as a new species (Liu et al., 2015). Li et al. (2016) reported Clarkeinda trachodes (Berk.) Singer, Lilloa based on both morphological characteristics and molecular phylogenetic analysis after Berkeley (1847) first described it. In addition, one coprophilous fungus (Panaeolus sphinctrinus (Fr) Quél.) and one grassland species (P. foenisecii (Pers.) J. Schröt.) were described from Sri Lankan dry zone forest reserves based on morphological characteristics and DNA sequences (Ediriweera et al. 2015).

More recently, Tipbromma et al. (2017) reported Boletellus emodensis (Berk.) Singer, Favolaschia auriscalpium (Mont.) Henn., F. manipularis (Berk.) Teng, Lentinus sajorcaju (Fr.) Fr., Leucocoprinus cretaceus (Bull.) Locq., Russula cf. virescens (Schaeff.) Fr. and Tremella fuciformis Berk. as new records to Sri Lanka with the support of morphological characteristics and DNA data, while Lentinus squarrosulus Mont. and L. velutinus Fr. were reported with the support of DNA data, following previous reports by Pegler (1983). Boletellus emodensis, L. sajor-caju, L. squarrosuIUS, $R$. virescens and T. fuciformis are edible mushrooms 
which grow wild in Sri Lanka, but most Sri Lankans are not aware that they are safe to eat.

\section{MUSHROOM CULTIVATION IN SRI LANKA}

Commercial mushroom cultivation was first introduced to Sri Lanka by the United Nations Development Programme (UNDP) in 1985. Spawn laboratories and mushroom houses for spawn production and mushroom cultivation were established by the Sri Lanka Export Development Board (Rajapakse, 2014). Subsequently, research and development activities connected to mushroom cultivation have been led by the Department of Agriculture as the state institution responsible for food crop production. The most popular cultivated species across the country in terms of production and consumption is Pleurotus ostreatus (Jacq.) P. Kumm., followed by P. cystidiosus O. K. Mill. and P. eous (Berk.) Sacc.

Even though the necessary technology for the cultivation of $P$. eryngii (D. C.) Quél. has been comprehensively developed by researchers (Anon, 2009), this has been restricted to the mid- and up country of Sri Lanka. Volvariella spp. (paddy straw mushroom) production is usually carried out outdoors in Sri Lanka (Rajapakse, 2014). The protocol for cultivation of button mushrooms in Sri Lanka [Agaricus bisporus (J. E. Lange) Imbach] was developed by Wijesinghe et al. (2000). Cultivation of milky mushroom (Callocybe indica Purkay. \& A. Chandra) and black ear mushrooms (Auricularia spp.) were first introduced to the country by Udugama and Wickramarathna (1991).

Ganoderma lucidum (Curtis) P. Karst. cultivation was refined by Rajapakse et al. (2010), while Bandaranayake et al. (2012) first reported cultivation technology and methods for domesticated G. lucidum. Methods for the successful artificial cultivation of the Sri Lankan endemic mushroom Pleurotus giganteus (Berk.) Karunarathna \& K.D. Hyde (Udugama and Wickramarathna, 1995) have been developed using sawdust. Recently, Namalee et al. (2016) published the commercial cultivation potential of P. giganteus, using locally adaptation of sawdust-based compost media under ambient tropical conditions - a method normally used for oyster mushroom cultivation (Figure 1).

\section{CONCLUSION AND RECOMMENDATIONS}

The proper identification of mushrooms, plant pathogenic fungi, and other fungi is an important part of Sri Lankan fungi research. Although several edible and medicinal mushrooms are found in Sri Lanka, most people are afraid to exploit this resource due to a widespread lack of mushroom knowledge. High school and university students, farmers and other local communities in Sri Lanka should be educated through workshops, conferences and guide books on how to safely make use of edible and medicinal mushrooms. If managed properly, the collection and cultivation of edible and medicinal mushrooms can provide a significant boost to rural incomes and nutrition.

Sri Lanka needs both a national fungi herbarium and culture collection, and a strong network of local fungi research groups. It is also vital to have a focal point for mycological activities within the national herbarium capable of managing the identification of all local fungi. Collaboration with other fungi research groups around the world is also vital in order for Sri Lankan scientists to stay abreast of new techniques and discoveries in fungi research. Sri Lankan mycologists should also be recognized for their hard work and persistence in developing this often neglected area of mycology.

\section{ACKNOWLEDGEMENTS}

We are grateful to Andrew Stevenson in the World Agroforestry Centre (ICRAF), East and Central Asia Office, Kunming Institute of Botany for English editing. We would like to thank CGIAR Research Program 6: Forest, Trees and Agroforestry, the Kunming Institute of Botany, Chinese Academy of Science (CAS) and the Chinese Ministry of Science and Technology, under the 12th 5-year National Key Technology Support Program (NKTSP) 2013BAB07B06 integration and comprehensive demonstration of key technologies on Green Phosphate-mountain Construction for providing the support for this study. Kevin D. Hyde thanks the Chinese Academy of Sciences, project number 2013T2S0030, for the award of Visiting Professorship for Senior International Scientists at Kunming Institute of Botany. Samantha C. Karunarathna thanks Yunnan Provincial Department of Human Resources and Social Security funded postdoctoral project (number 179122) for supporting his postdoctoral research study.

\section{BIBLIOGRAPHY}

Anonimous (2009) Administrative report. Department of Agriculture. Sri Lanka. $51 \mathrm{p}$

Bandaranayake E. M. L. O. K., P. Rajapakse and N. S. Weerakkody (2012) Selection of suitable saw dust as growing media for Reishi mushroom (Ganoderma lucidum) cultivation. Annual Academic Session, Open University of Sri Lanka. ISSN 2012-9112. pp:21-24 (retrieved from digital.lib.ou.ac.lk 03.07.2014).

Berkeley M. J. and C. E. Broome (1870) On some species of the genus Agaricus from Ceylon. Transactions of the Linnean Society of London 27:149-152.

Berkeley M. J. and C. E. Broome (1871) The Fungi of Ceylon (Hymenomycetes from Agaricus to Cantharellus). Botanical Journal of the Linnean Society 11:494-567.

Berkeley M. J. and C. E. Broome (1873) Enumeration of the Fungi of Ceylon. Part 2. Botanical Journal of Linnean Society 14: 29-140.

Cesati V. and 0. Beccari (1879) Mycetum in itinere Borneensi lectorum a cl. Od. Beccari. Neapoli: Typis Regiae Scientiarum Academiae 8:1-28. 

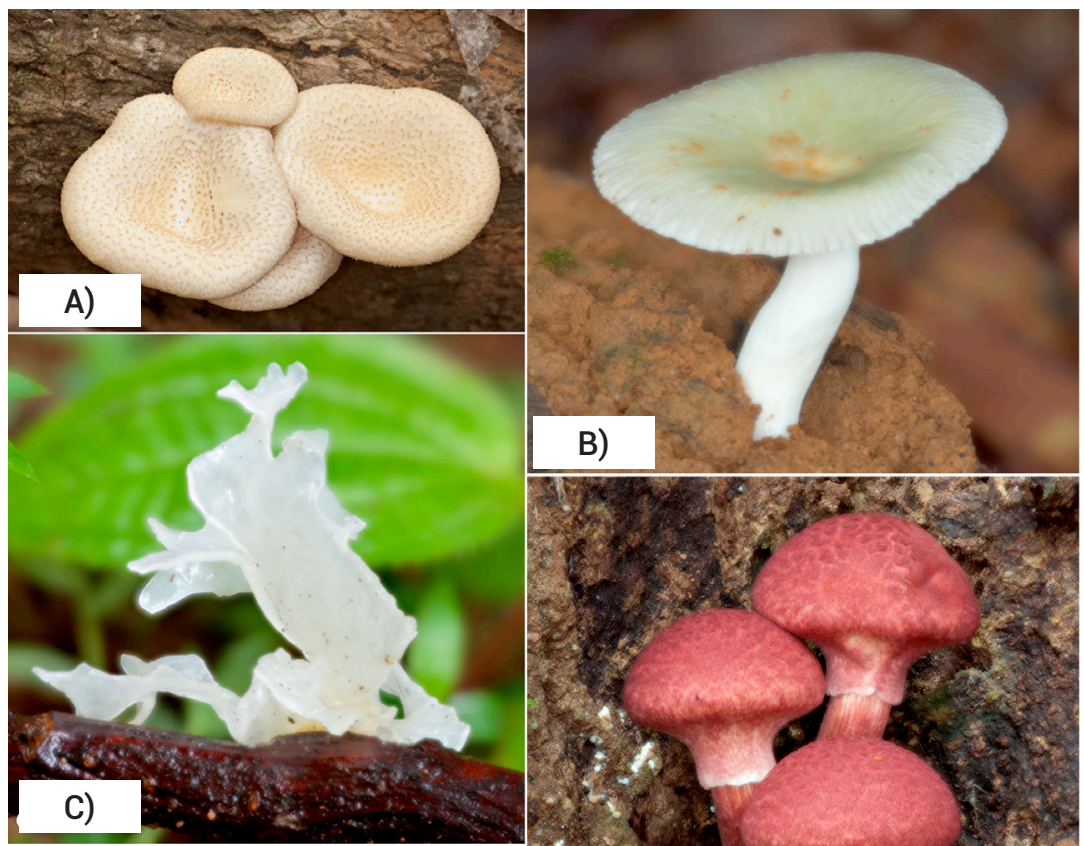

B)
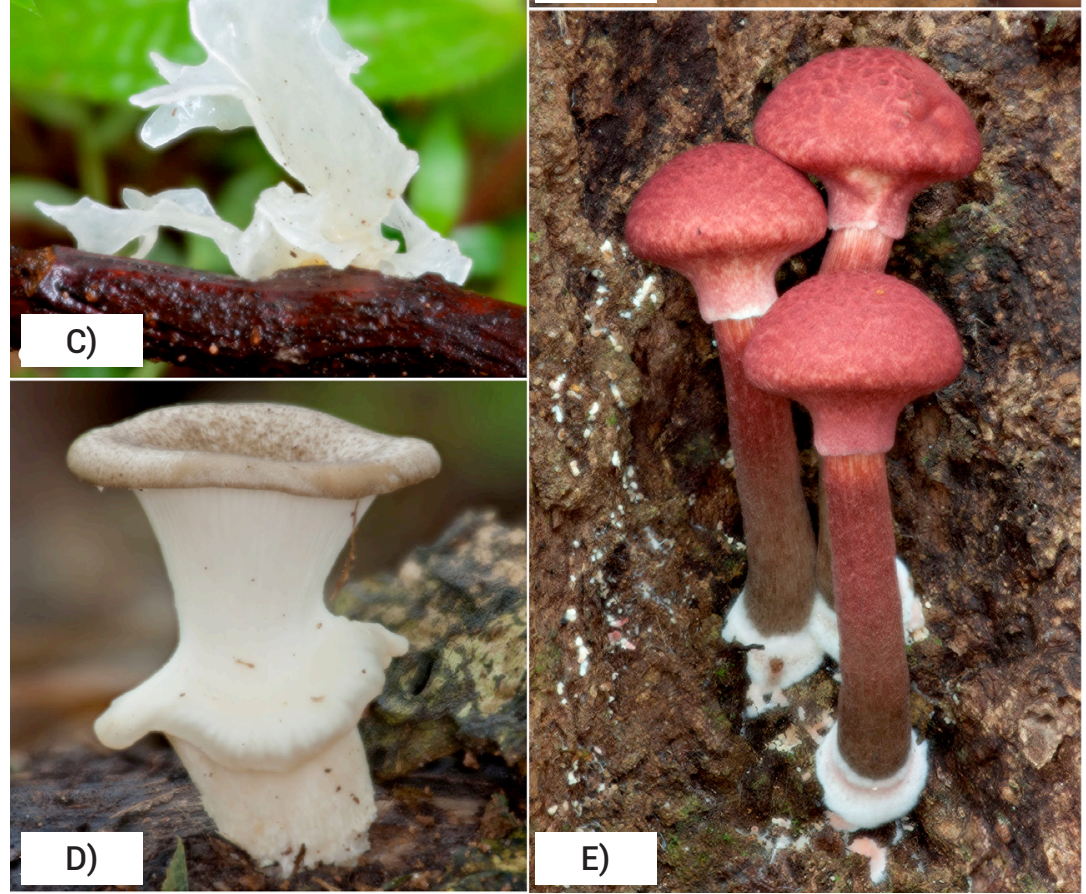

Figure 1. Edible mushrooms recorded in Tipbromma et al. (2017) A) Lentinus squarrosulus. B) Russula cf. virescens. C) Tremella fuciformis- D) Lentinus sajor-caju. E) Boletellus emodensis.

Coomaraswamy U. (1979a) A Handbook to the Fungi Parasitic on the Plants of Sri Lanka. MAB-UNESCO Publication No. 4. National Science Council. Sri Lanka.

Coomaraswamy U. (1979b) A Handbook to the Agarics of Sri Lanka. MAB-UNESCO Publication No. 5. National Science Council. Sri Lanka. $122 \mathrm{p}$

Coomaraswamy U. and R. N. De Fonseka (1981) A Handbook to the Soil Fungi of Sri Lanka. MAB-UNESCO Publication No. 7. National Science Council. Sri Lanka. 122 p.

Coomaraswamy U. and S. Kumarasingham (1988) A Handbook to the Macrofungi of Sri Lanka. Natural Resources, Energy and Science Authority. Sri Lanka. 124 p.

Ediriweera S., R. L. C. Wijesundera, C. Nanayakkara and J. Weerasena (2015) First report of Panaeolus sphinctrinus and Panaeolus foenisecii (Psathyrellaceae, Agaricales) on elephant dung from Sri Lanka. Frontiers in Environmental Microbiology 1:19-23.

Höehnel F. (1908) Fragmente zur Mycologie V. Nr. 169 bis 181. Akademie der Wissenschaften In Wien. Mathematisch naturwissenschaftliche Klasse 117:1-48.

Höehnel F. (1909) Fragmente zur Mycologie VI. Nr. 182 bis 288. Akademie der Wissenschaften In Wien. Mathematisch naturwissenschaftliche Klasse 118:1-178.

Höehnel F. (1914) Fragmente zur Mycologie XVI. Nr. 813 bis 875. Akademie der Wissenschaften In Wien. Mathematisch naturwissen- schaftliche Klasse 123:1-107

Horak E. (1979) Astrosporina (Agaricales) in Indomalaya and Australasia. Persoonia 10:157-205

Horak E. (1980) Inocybe (Agaricales) in Indomalaya and Australasia. Persoonia 11:1-37

Houttuyn M. (1783) Handleiding tot de plant - en kruidkunde, benevens eene uitvoerige beschrijving der boomen, planten, heesters, kruiden, varens, mossens, bollen grasplanten, volgens het zamenstel van C. Linnaeus. Bij Lodewyk van Es 14:585-698.

Karunarathna S. C., Z. L. Yang, O. Raspé, T. W. Ko Ko, E. C. Vellinga, R. L. Zhao, A. H. Bahkali, E. Chukeatirote, J. Degreef, P. Callac and K. D. Hyde (2011) Lentinus giganteus revisited: new collections from Sri Lanka and Thailand. Mycotaxon 118:57-71.

Li G. J., k. D. Hyde, R. L. Zhao, S. Hongsanan, F. A. Abdel-Aziz, M. A. AbdelWahab, P. Alvarado, G. Alves-Silva, J. F. Ammirati, H. A. Ariyawansa, A. Baghela, A. H. Bahkali, M. Beug, D. J. Bhat, D. Bojantchev, T. Boonpratuang, T. S. Bulgakov, E. Camporesi, M. C. Boro, O. Ceska, D. Chakraborty, J. J. Chen, k. W. T. Chethana, P. Chomnunti, G. Consiglio, B. K. Cui, D. Q. Dai, Y. C. Dai, D. A. Daranagama, K. Das, M. C. Dayarathne, E. D. Crop, R. J. V. De Oliveira, C. A. Fragoso de Souza, J. I. de Souza, B. T. M. Dentinger, A. J. Dissanayake, M. Doilom, E. R. Drechsler-Santos, M. Ghobad-Nejhad, S. P. Gilmore, A. Góes-Neto, M. Gorczak, G. H. Haitjema, K. K. Hapuarachchi, A. Hashimoto, M. Q. He, J. K. Henske, K. Hirayama, M. J. Iribarren, S. C. Jayasiri, R. S. Jayawardena, S. J. Jeon, G. 
H. Jerônimo, A. L. Jesus, E. B. G. Jones, J. C. Kang, S. C. Karunarathna, P. M. Kirk, S. Konta, E. Kuhnert, E. Langer, H. S. Lee, H. B. Lee, W. J. Li, X. H. Li, K. Liimatainen, D. X. Lima, C. G. Lin, J. K. Liu, X. Z. Liu, Z. Y. Liu, J. J. Luangsa-ard, R. Lücking, H. T. Lumbsch, S. Lumyong, E. M. Leaño, A. V. Marano, M. Matsumura, E. H. C. McKenzie, S. Mongkolsamrit, P. E. Mortimer, T. T. T. Nguyen, T. Niskanen, C. Norphanphoun, M. A. O'Malley, S. Parnmen, J. Pawłowska, R. H. Perera, R. Phookamsak, C. Phukhamsakda, C. L. A. Pires-Zottarelli, O. Raspé, M. A. Reck, S. C. O. Rocha, A. L. C. M. A. de Santiago, I. C. Senanayake, L. Setti, Q. J. Shang, S. K. Singh, E. B. Sir, K. V. Solomon, J. Song, P. Srikitikulchai, M. Stadler, S. Suetrong, H. Takahashi, T. Takahashi, K. Tanaka, L. P. Tang, K. M. Thambugala, D. Thanakitpipattana, M. K. Theodorou, B. Thongbai, T. Thummarukcharoen, Q. Tian, S. Tibpromma, A. Verbeken, A. Vizzini, J. Vlasák, K. Voigt, D. N. Wanasinghe, Y. Wang, G. Weerakoon, H. A. Wen, T. C. Wen, N. N. Wijayawardene, S. Wongkanoun, M. Wrzosek, Y. P. Xiao J. C. Xu, J. Y. Yan, J. Yang, S. D. Yang, Y. Hu, J. F. Zhang, J. Zhao, L. W. Zhou, D. Peršoh, A. J. L. Phillips and S. S. N. Maharachchikumbura (2016) Fungal diversity notes 253-366: taxonomic and phylogenetic contributions to fungal taxa. Fungal Diversity 78:1-237

Liu J. K., K. D. Hyde, E. B. G. Jones, H. A. Ariyawansa, D. J. Bhat, S. Boonmee, S. S. N. Maharachchikumbura, E. H. C. McKenzie, R. Phookamsak, C. Phukhamsakda, B. D. Shenoy, M. A. Abdel-Wahab, B. Buyck, J. Chen, K. W. T. Chethana, C. Singtripop, D. Q. Dai, Y. C. Dai, D. A. Daranagama, A. J. Dissanayake, M. Doilom, M. J. Dsouza, X. L. Fan, I. D. Goonasekara, K. Hirayama, S. Hongsanan, S. C. Jayasiri, R. S. Jayawardena, S. C. Karunarathna, W. J. Li, A. Mapook, C. Norphanphoun, K. L. Pang, R. H. Perera, D. Peršoh, U. Pinruan, I. C. Senanayake, S. Somrithipol, S. Suetrong, K. Tanaka, K. M. Thambugala, Q. Tian, S. Tibpromma, D. Udayanga, N. N. Wijayawardene, D. N. Wanasinghe, K. Wisitrassameewong, X. Y. Zeng, F. A. Abdel-Aziz, S. Adamčík, A. H. Bahkali, N. Boonyuen, T. Bulgakov, P. Callac, P. Chomnunti, K. Greiner, A. Hashimoto, V. Hofstetter, J. C. Kang, D. Lewis, X. H. Li, X. Z. Liu, Z. Y. Liu, M. Matsumura, P. E. Mortimer, G. Rambold, E. Randrianjohany, G. Sato, V. Sri-Indrasutdhi, C. M. Tian, A. Verbeken, W. von Brackel, Y. Wang, T. C. Wen, J. C. Xu, J. Y. Yan, R. L. Zhao and E. Camporesi (2015) Fungal Divers notes 1-110: taxonomic and phylogenetic contributions to fungal species. Fungal Diversity 72:1-197

Namalee D. G. A., H. M. R. Sarasi, S. Udugama, K. L. W. Kumara (2016) Cultivation potential of Lentinus giganteus (Urupaha): A wild edible mushroom of Sri Lanka. Science and Cultivation of Edible Fungi, Baars \& Sonnenberg 19 Article 41:200-203.

Pegler D. N. (1972) A revision of the genus Lepiota from Ceylon. Kew Bulletin 27:155-222.

Pegler D. N. (1977) A revision of Entolomataceae (Agaricales) from India and Sri Lanka. Kew Bulletin 32:189-220.

Pegler D. N. (1983) The Genus Lentinus: A World Monograph. H. M. S. O. London. $281 \mathrm{p}$.

Pegler D. N. (1986) Agaric flora of Sri Lanka. Kew Bulletin Additional series 6, office. M. S. O. London. 519 p.

Petch T. and G. R. Bisby (1950) The Fungi of Ceylon. Peradeniya Manual 6. Colombo, Government Pub. Bureau. Sri Lanka. 111 p.

Petch T. (1908a) The Phalloideae of Ceylon. Annals of the Royal Botanic Gardens, Peradeniya 4:139-184.

Petch T. (1908b) The genus Endocalyx, Berkeley and Broome. Annals of Botany 22:389-400.

Petch T. (1910) Revisions of ceylon fungi (Part II). Annals of the Royal Botanic Gardens, Peradeniya 4:373-444

Petch T. (1913) Termite fungi: a résumé. Annals of the Royal Botanic Gardens, Peradeniya 5:303-341.

Petch T. (1915a) The pseudo-sclerotia of Lentinus similis and Lentinus infundibuliformis. Annals of the Royal Botanic Gardens, Peradeniya 6:1-18.

Petch T. (1915b) Horse-hair blights. Annals of the Royal Botanic Gardens, Peradeniya 6:43-68.

Petch T. (1916a) A preliminary list of Ceylon Polypori. Annals of the
Royal Botanic Gardens, Peradeniya 6:87-144

Petch T. (1916b) Ceylon lentini. Annals of the Royal Botanic Gardens, Peradeniya 6:145-152.

Petch T. (1916c) Revisions of ceylon fungi (Part IV). Annals of the Royal Botanic Gardens, Peradeniya 6:153-183.

Petch T. (1917a) Additions to ceylon fungi. Annals of the Royal Botanic Gardens, Peradeniya 6:195-256.

Petch T. (1917b) Revisions of ceylon fungi (Part V). Annals of the Royal Botanic Gardens, Peradeniya 6:307-355.

Petch T. (1919) Revisions of ceylon fungi (Part VI). Annals of the Royal Botanic Gardens, Peradeniya 7:1-14.

Petch T. (1922) Additions to ceylon fungi II. Annals of the Royal Botanic Gardens, Peradeniya 7:279-322

Petch T. (1923) The Diseases of the Tea Bush. .MacMillan \& Co. Ltd. London, UK. $220 \mathrm{p}$.

Petch T. (1924a) Thread blights. Annals of the Royal Botanic Gardens, Peradeniya 9:1-46.

Petch T. (1924b) Revisions of ceylon fungi (Part. VII). Annals of the Royal Botanic Gardens, Peradeniya 9:119-181.

Petch T. (1924c) Ceylon pink-spored agarics. Annals of the Royal Botanic Gardens, Peradeniya 9:201-216.

Petch T. (1924d) Agaricaceae pleuropods Zeylanicae. Annals of the Royal Botanic Gardens, Peradeniya 9:217-227.

Petch T. (1925) Additions to ceylon fungi III. Annals of the Royal Botanic Gardens, Peradeniya 9:313-328.

Petch T. (1926a) Additions to ceylon fungi IV. Annals of the Royal Botanic Gardens, Peradeniya 10:131-138.

Petch T. (1926b) Rhacophyllus B. \& Br. Transactions of the British Mycological Society 11:238-251.

Petch T. (1927) Revisions of ceylon fungi VIII. Annals of the Royal Botanic Gardens, Peradeniya 10:161-180.

Petch T. (1928) Tropical root disease fungi. Transactions of the British Mycological Society 13:238-253

Petch T. (1945) Ceylon fungi, old and new. Transactions of the British Mycological Society 27:137-147.

Petch T. (1947) A revision of Ceylon Marasmii. Transactions of the British Mycological Society 31:19-44.

Rajapakse J. C. (2014) Status of edible and medicinal mushroom research in Sri Lanka. In: Proceedings of the 8th International Conference on Mushroom Biology and Mushroom Products (ICMBMP8). M. Singh (ed.). Volume I \& II. New Delhi, India. 19 - 22 November. : ICAR-Directorate of Mushroom Research. Solan, India. pp:417-421.

Rajapakse J. C., C. Nanayakkara, R. Samarasekara, I. J. De Zoysa and A Karunatilake (2010) Cultivation possibilities of some selected Sri Lankan indigenous mushrooms with special reference to Ganoderna lucidum (Fr.) Karst. In: Annual Research Proceedings University of Colombo, Sri Lanka. 12-13 May.pp:117.

Tipbromma S., K. D. Hyde, R. Jeewon, S. S. N. Maharachchikumbura, J. K. Liu, D. J. Bhat, E. B. G. Jones, E. H. C. McKenzie, E. Camporesi, T. S. Bulgakov, M. Doilom et al. (2017) Fungal diversity notes 491-602: taxonomic and phylogenetic contributions to fungal taxa. Fungal Diversity 83:1-261

Udugama S. and K. Wickramaratna (1991) Artificial production of naturally occurring Lentinus giganteus (Uru Paha), a Sri Lankan edible mushroom. Horticultural Crop Research \& Development Institute (HORDI), Gannoruwa, Peradeniya.

Udugama S. and K. Wickramaratna (1995) Artificial production of naturally occurring Lentinus giganteus (Uru paha mushroom): A Sri Lankan edible mushroom. Proceedings of Sri Lanka Association For the Advancement of Science 51.

Wijesinghe M. A. K., I. K. Warsamana, P. Rajapakse and A. C. M. Mazeen (2000) Production of Agaricus bisporus white button mushroom under local condition. Proceedings of Annual Symposium of the Department of Agriculture, Sri Lanka 2:345-347. 
